\title{
Material and Energy Requirement for Rare Earth Production
}

\author{
LAURA TALENS PEIRÓ ${ }^{1,3}$ and GARA VILLALBA MÉNDEZ ${ }^{2,4}$ \\ 1.-INSEAD—Campus Europe, Boulevard de Constance, 77305 Fontainebleau, France. \\ 2.-Department of Chemical Engineering, Edifici Q, Universitat Autònoma de Barcelona (UAB), \\ 08193Bellaterra, Barcelona, Spain. 3.—e-mail: laura.talens@gmail.com. 4.—e-mail: gara.villalba@ \\ uab.cat
}

\begin{abstract}
The use of rare earth metals (REMs) for new applications in renewable and communication technologies has increased concern about future supply as well as environmental burdens associated with the extraction, use, and disposal (losses) of these metals. Although there are several reports describing and quantifying the production and use of REM, there is still a lack of quantitative data about the material and energy requirements for their extraction and refining. Such information remains difficult to acquire as China is still supplying over $95 \%$ of the world REM supply. This article attempts to estimate the material and energy requirements for the production of REM based on the theoretical chemical reactions and thermodynamics. The results show the material and energy requirement varies greatly depending on the type of mineral ore, production facility, and beneficiation process selected. They also show that the greatest loss occurs during mining (25-50\%) and beneficiation (10-30\%) of RE minerals. We hope that the material and energy balances presented in this article will be of use in life cycle analysis, resource accounting, and other industrial ecology tools used to quantify the environmental consequences of meeting REM demand for new technology products.
\end{abstract}

\section{INTRODUCTION}

In the past few years, rare earth metals (REMs) have received special attention because they are considered critical. In general, a resource is critical when it is scarce, is subject to potential supply constraints, costly, and is needed for a particular function where substitutes are inferior. ${ }^{1-5}$ Although REMs are relatively abundant in the Earth's crust, discovered minable concentrations are mostly located in China, which provided over $95 \%$ of output in 2011. The remaining sources are in the United States-where the mine at Mountain Pass in California resumed operations-plus Australia, India, Malaysia, and Brazil. ${ }^{6}$ Exploration to find rare earth ore deposits outside China continues, especially as the export limits and the ban on new mining permits in China continues. Talens Peiró et al. ${ }^{p}$ showed that most scarce metals, including REMs, are distributed as trace elements-regarded as "hitch hikers"-with mineral ores of certain similar metals found in higher concentrations called "attractors." As attractors and hitch hikers are very chemically and physically similar, their separation becomes the most important step during mineral processing. Separation at environmental temperature using basic chemical principles such as density, solubility, surface properties, and magnetic properties becomes the "ideal" processes as they need little energy input. For some metals, however, separation is based on melting points and electrical conductivity, which have greater energy requirements.

Mineral ores containing REMs are processed using standard methods for mining, extraction, and refining. However, their beneficiation and the separation of REMs into individual $\mathrm{RE}$ elements require more specific processes. The reactant used for chemical beneficiation depends on the chemical form of the REM in the mineral ore. Thus, REMs contained in bastnäsite are beneficiated by digestion using sulfuric acid, hydrochloric acid and by direct chlorination. Monazite is beneficiated by an acid or an alkali agent, whereas REMs in xenotime are obtained by sulfuric acid digestion. REMs are obtained as mixtures of chlorides, oxides, nitrates, and fluorides, which are later separated into individual REMs by solvent extraction using organic solvents. 
Although process flowsheets describing the processes required for the production of REMs exist, there are no studies yet providing a comprehensive material and energy analysis of the production of REMs. ${ }^{8,9}$ Quantitative data about beneficiation and REM separation still remain confidential and are rarely available in industry reports or process descriptions. For instance, Ecoinvent, the reference database for consistent life cycle inventory data, does not include such information. As REMs are becoming essential in many applications, a detailed analysis of their production is needed to provide concise data for life cycle analysis, environmental evaluation, and economic analysis. In this article, we use basic chemistry and physics principles to quantify the material and energy requirements for the production of REMs. This article focuses especially on the chemical beneficiation of REs for each type of mineral ore: bastnäsite, monazite, and xenotime. The process description includes recovery rates and estimates about the losses occurring during processing, all of which are useful in identifying areas for potential improvement and quantifying wastes that may become an additional source of these metals in the future.

\section{TYPES OF RARE EARTHS MINERALS AND THEIR PRODUCTION}

About 17 REMs are usually found together, mostly in three major minerals: bastnäsite with iron in Bayan Obo (Inner Mongolia), monazite and xenotime ores with radioactive thorium (Mountain View, California, and Kerala, India), and ion-adsorption clays. ${ }^{10,11}$ More than $95 \%$ of the rare earths occur in bastnäsite, monazite, and xenotime. ${ }^{12}$ Bastnäsite contains about $70-75 \%$ rare earth oxides (REOs), monazite $65-70 \%$, and xenotime $61-67 \% .^{9,11}$ Bastnäsite ores $\left([\mathrm{Ce}, \mathrm{La}, \mathrm{Nd}]\left(\mathrm{CO}_{3}\right) \mathrm{F}\right)$ are fluorocarbonates of cerium, lanthanum, neodymium, and other REMs. They occur in carbonatites, quartz veins, and epithermal fluorite-bearing veins. The world's largest deposit is at Bayan Obo in Inner Mongolia, where bastnäsite occurs together with monazite and other iron-bearing ores. In Bayan Obo, the main metals and minerals extracted are iron, rare earths, niobium, and fluorite. Bastnäsite is the least problematic source of REO, as it hardly contains any radioactive thorium. ${ }^{9,13}$

Monazite $\left([\mathrm{Ce}, \mathrm{La}, \mathrm{Nd}]\left(\mathrm{PO}_{4}\right)\right)$ is a phosphate mainly formed with cerium, lanthanum, and neodymium elements. It occurs in igneous rocks, metamorphic rocks, and vein deposits, but the most important commercial source is from beach placers and sand deposits. The distribution of rare earth in monazite is variable and two samples from different locations hardly ever have the same distribution of mixed rare earth. ${ }^{12}$

Xenotime $\left(\mathrm{YPO}_{4}\right)$ is also a phosphate that contains up to $63 \%$ yttrium oxide. It is a minor constituent of granite or gneiss and co-occurs in placer deposits.
Commercially significant quantities occur in Malaysia, Indonesia, and Thailand. In Australia and China, xenotime occurs in association with ilmenite, rutile, and zircon-containing heavy mineral sands. In Brazil, there are recoverable quantities in the alluvial tin mine in the state of Amazonas.

Ion-adsorption clays are formed by the weathering of rare-earth-rich primary granite-type rock or volcanic rock followed by the adsorption of soluble rare earth species on clays. The weathering process also modifies the proportion of the various rare earths originally found in the source rock. Thus, the composition varies widely depending on the ore location. ${ }^{9}$ In general, they are rich in yttrium and mid-rare earths as europium, samarium, and gadolinium. Apart from the major sources briefly noted, there are others rare earth minerals that are potentially important: euxenite $((\mathrm{Y}, \mathrm{Ca}, \mathrm{Ce}, \mathrm{U}, \mathrm{Th})(\mathrm{Nb}, \mathrm{Ta}$, $\left.\mathrm{Ti})_{2} \mathrm{O}_{6}\right)$ and gadolinite $\left(\mathrm{Be}_{2} \mathrm{FeY}_{2} \mathrm{Si}_{2} \mathrm{O}_{10}\right)$, although there is no large-scale processing of these currently.

The amount of each REM contained in different types of mineral ores and in different mine deposits is presented in Table I. The composition of each mineral varies from mine to mine depending on their location. In general, cerium, lanthanum, neodymium, and praseodymium are found in greater amounts in bastnäsite and monazite. Yttrium together with other mid- and heavy rare earths as dysprosium and ytterbium is contained in greater concentration in xenotime and ion-adsorption clay.

In 2010, about 54,000 tonnes of rare earths were produced from bastnäsite in iron ores, 12,000 tonnes from bastnäsite, 11,000 from monazite and xenotime, and 37,000 from ion-adsorption clays, which totaled almost 114,000 tonnes in $2010 .^{7}$ There is a first group of REMs produced in annual amounts greater than 10,000 tonnes (cerium, lanthanum, neodymium, and yttrium), a second group that includes praseodymium and dysprosium, both of which are produced in thousands of tonnes. Then, a last group of REMs formed by gadolinium, samarium, europium, and terbium all are produced in the order of hundreds of tonnes. Metals produced in amounts lower than 10,000 tonnes can be regarded as "hitch hikers" or by-products of lanthanum, cerium, neodymium, and yttrium. ${ }^{7}$

For simplification purposes, we assume an average molecular weight of $120 \mathrm{~g} / \mathrm{mol}$ of REM. When the amounts are given as REOs, they include the amount of oxygen associated with the REM. The molecular weight of $\mathrm{REO}\left(\mathrm{RE}_{2} \mathrm{O}_{3}\right)$ assumed is $288 \mathrm{~g} / \mathrm{mol}$. Thus, each tonne of REO is approximately composed by $83 \%$ REM and $17 \%$ oxygen. As an estimate, 1.20 tonnes of $\mathrm{REO}$ is equivalent to 1 tonne of REM.

\section{STAGES OF THE EXTRACTION AND PRODUCTION OF RARE EARTHS}

The production of REMs can be divided in three main stages: mineral processing, reduction, and refining. Mineral processing includes mining, 


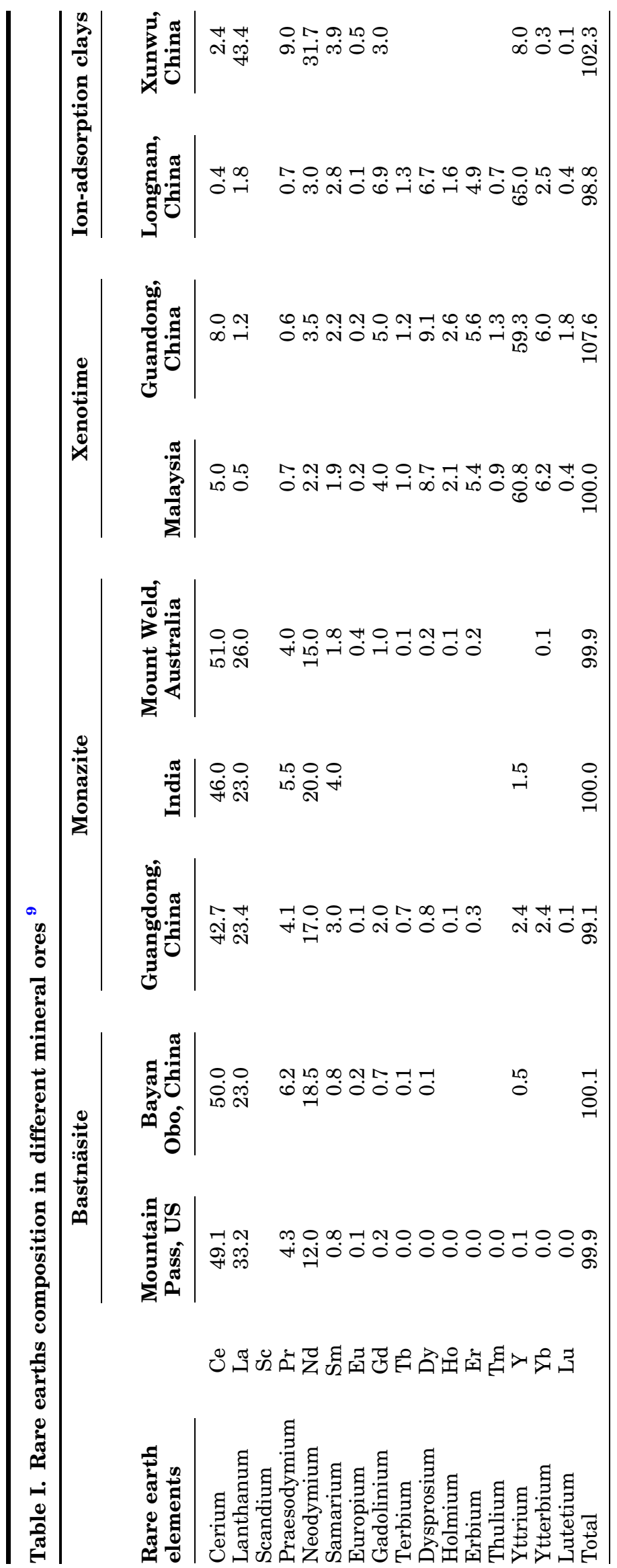




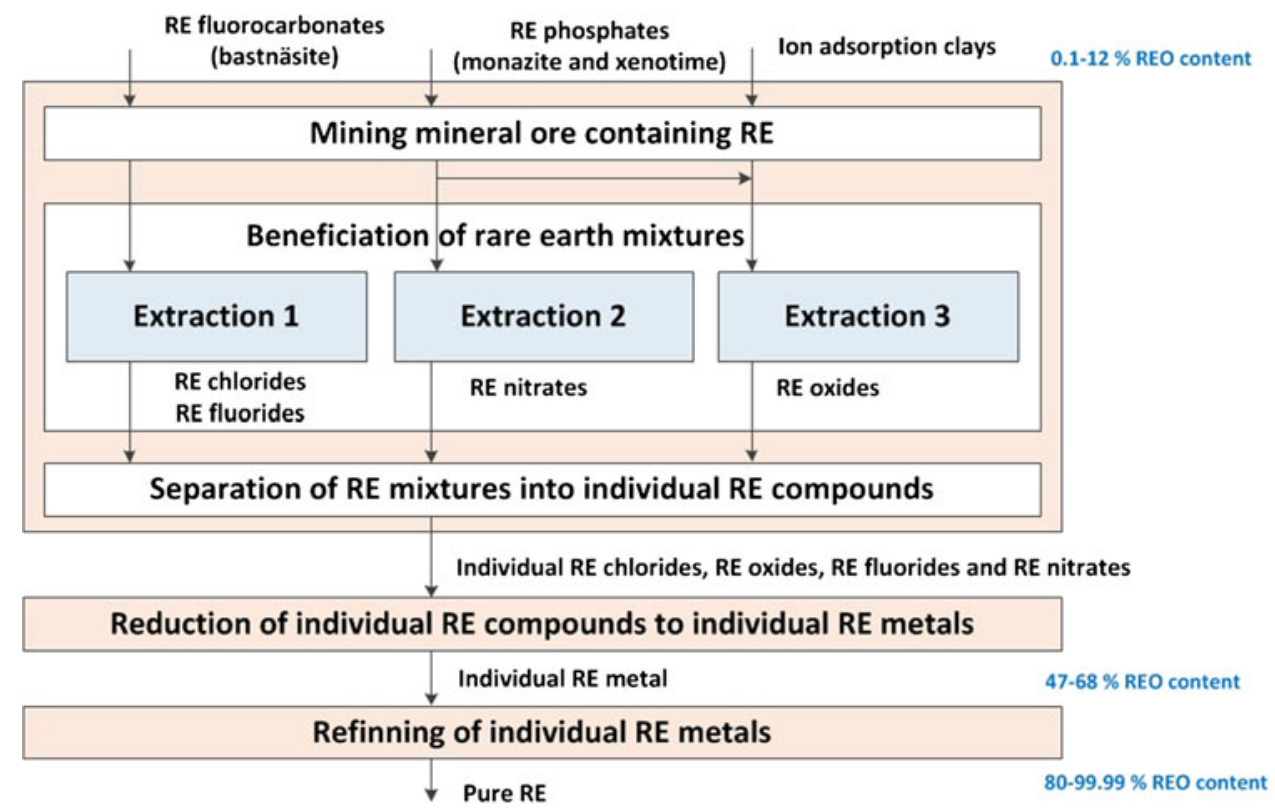

Fig. 1. Flowsheet of the production of rare earth metals.

beneficiation, and the separation of each REM. REMs are open-pit mined using standard methods such as drill, blast, load, and haul. Then, they are physically beneficiated by separating finely divided minerals with similar physical properties and treated to extract REM. REMs contained in bastnäsite can be extracted by digestion using sulfuric acid and hydrochloric acid, and by direct chlorination. Monazite is treated by an acid or an alkali agent, whereas REMs in xenotime are obtained by sulfuric acid digestion. The extracted REMs are then separated by solvent extraction, which is selected based on the chemical form of RE: chlorides, oxides, nitrates, and sulfates. Once REMs are separated, they are reduced by fused salt electrolysis or metallothermic reduction. Finally, REMs are refined to reduce the amount of impurities and obtain metals in 98-99\% purity. Figure 1 shows a simplified flowsheet showing the stages for processing RE minerals and an approximate content of REO in each stage. In this article, we exclude the refining of individual $\mathrm{RE}$ as it depends on the final use and purpose of the metal.

The material and energy requirements are estimated theoretically using technical descriptions on process conditions, chemical reactions, and energy use. Major sources of information were based on literature information. ${ }^{8,9,14-16}$ Data regarding the production of rare earths are generally given per tonne of ore mined or tonne of REO. The amount of primary ore mined and processed to obtain 1 tonne of REM depends on the amount of REO contained in the ore and the recovery rate of REO. For example, the mineral ore from Bayan Obo contains 4.1\% REO, whereas ore from Mountain Pass contains an average amount of $7.7 \%$ REO. ${ }^{11}$ The recovery rate of mineral resources varies from mine to mine and depends on the type of mineral ore. In Bayan Obo, the recovery rate of bastnäsite and monazite increased from less than $10 \%$ in 2005 to about $60 \%$ in state-owned and to $40 \%$ in individually owned enterprises. ${ }^{17}$ By 2016, the recovery rate of those mines is expected to rise $75 \%$. The recovery rate of mining and concentrating bastnäsite in Sichuan is less than $50 \%$, while that of in situ leaching of ionadsorption clays increased from $26 \%$ to $75 \%$ from 1970 s to the present. ${ }^{18}$ As result, for our calculations we use different recovery rates for the material and energy estimates based on data available. The results are generally expressed per tonne of REM.

\section{Mineral Processing}

Mineral processing includes the mining, beneficiation, and separation of rare earth. Although all rare earth minerals are generally open-pit mined, the energy requirement for crushing and grinding varies depending on their hardness and the gangue minerals associated. The physical and chemical beneficiation of bastnäsite is different from that of monazite and xenotime, as bastnäsite is a carbonate-fluoride mineral, and monazite and xenotime are both phosphate minerals. The separation of REMs depends on the chemical form in which they are extracted. The following section provides a detailed explanation of the processes and reactions involved for the processing of each type of $\mathrm{RE}$ mineral ores. At the end of the section, we include a table showing the material and energy inputs and outputs for each process. 


\section{Mining and Grinding Rare Earths Containing Minerals}

About 95\% of REMs occur in three minerals: bastnäsite, monazite, and xenotime. The larger rare earth mine is located in Bayan Obo (China) and Mountain Pass (United States). The Bayan Obo mine contains bastnäsite and monazite together with hematite and martite $\left(\mathrm{Fe}_{2} \mathrm{O}_{3}\right)$, magnetite $\left(\mathrm{Fe}_{3} \mathrm{O}_{4}\right)$, and rutile $\left(\mathrm{TiO}_{2}\right)$. In Mountain Pass, the principal minerals occurring are $60 \%$ calcite $\left(\mathrm{CaCO}_{3}\right), 20 \%$ barite $\left(\mathrm{BaSO}_{4}\right), 10 \%$ bastnäsite, and the remaining $10 \%$ of other minerals such as silica $\left(\mathrm{SiO}_{2}\right)$. Typical hard rock ores are mined from the surface by open-pit methods. The ore is blasted, loaded into trucks and transported to a mill. Then, it is processed by crushing and grinding until at least $90 \%$ of the particles are no bigger than $0.15 \mathrm{~mm}$. At Mountain Pass, the primary ore is crushed in a jaw crusher in series with a cone crusher and then to a rod mill, which produces a $1.65-\mathrm{mm}$ material that is later fed to a classifier in a closed circuit with a conical ball mill. The classifier feeds the material to four agitators. The first three agitators heat the slurry up to $93^{\circ} \mathrm{C}$, whereas the fourth cools the slurry to $60^{\circ} \mathrm{C}$. Subsequently, the granules are sent to flotation. ${ }^{19}$

Gupta estimated that the energy requirement associated to the open-pit mining, crushing, and grinding operations is in the range of $0.35-0.45 \mathrm{GJ} /$ tonne of ore mined and processed. Fine grinding is the most energy-intensive process and requires from $0.11 \mathrm{GJ}$ to $0.28 \mathrm{GJ} /$ tonne of ore depending on the hardness of the rock. ${ }^{14}$ The energy required to grind primary ores containing rare earths can be estimated based on the hardness of the mineral. Bastnäsite has 4-5 Mohs of hardness, similar to that of apatite $\left(\mathrm{Ca}_{5} \mathrm{~F}\left(\mathrm{PO}_{4}\right)_{3}\right){ }^{20}$ Consequently, the energy required for grinding bastnäsite is similar than of apatite to $0.15 \mathrm{~mm}$ and is estimated to be $0.06 \mathrm{GJ} /$ tonne of primary ore. ${ }^{8}$ This value is in line with the estimate given by the U.S. Bureau of Mines, which says that the energy to mine, crush, grind, and condition tonne of ore containing bastnäsite is $0.1 \mathrm{GJ}$ and that almost two-thirds of the energy is spent only for grinding. ${ }^{19}$

The energy input for processing 1 tonne of REMs varies depending on its concentration in the primary ore mined. At Mountain Pass, the ore mined contains an average of $7.7 \%$ of REO and the recovery rate is about $90 \%$ due to a very fine grinding of the minerals. ${ }^{21}$ Thus, 17 tonnes of mineral ores and an energy input of 1.74 GJ are needed to extract of 1 tonne of REM. At Bayan Obo, the mineral ore contains $4.1 \%$ of REO and the average recovery rate is 50\%; consequently, the extraction of 1 tonne of REM requires mining almost 50 tonnes of mineral ore and 6 GJ of energy input.

Monazite and xenotime have hardness values of about 5 Mohs, both of which are similar to that of apatite. Most importantly, monazite resources and xenotime have already undergone weathering, transportation, and concentration processes as they co-occur in beach placers. As a result, none of these minerals require crushing and grinding operations. Gupta and Krishnamurthy estimated that the energy required for mining placer deposits varies from 0.02 GJ to $0.07 \mathrm{GJ} /$ tonne of ore, mostly for physical concentration. ${ }^{9}$ Based on the amount of energy estimated by the Bureau of Mines, we calculate that each tonne of mineral ore containing REM requires about $0.4 \mathrm{GJ}^{19}$ The grades of ion-adsorption deposits are the lowest containing 0.05-0.2\% REO. The average ore grade of placer deposits containing monazite and xenotime in China is $0.5-1 \%$ REO. Thus, to obtain 1 tonne of REM, 160 tonnes of mineral ores and about 6.4 GJ of energy are needed. $^{22}$ Table II summarizes the REO grade, recovery rate of REO, the tonnes of mineral ores mined to recover 1 tonne of REM, and the energy required for such recovery.

\section{Beneficiation of Rare Earths}

Bayan Obo Mineral Ore In Bayan Obo, REMs are obtained from nonmagnetic tailings during the beneficiation of hematite $\left(\mathrm{Fe}_{2} \mathrm{O}_{3}\right)$. The beneficiation of Bayan Obo mineral ore includes the flotation and the chemical beneficiation of REM by roasting with sulfuric acid. During flotation, $\mathrm{RE}$ concentrates are exposed to $\mathrm{Na}_{2} \mathrm{CO}_{3}$ as a $\mathrm{pH}$ regulator, and $\mathrm{Na}_{2} \mathrm{SiO}_{3}$ and $\mathrm{NaSiF}_{6}$ as gangue depressants. The concentrates contain 56\% REO from both bastnäsite and monazite sources. ${ }^{12}$ Bastnäsite is separated from monazite due to the difference of their specific gravities using a shaking table. The bastnäsite and

Table II. Details of the mining in Bayan Obo, Mountain Pass, and placer deposits ${ }^{9}$

\begin{tabular}{|c|c|c|c|}
\hline & $\begin{array}{l}\text { Bastnäsite } \\
\text { Bayan Obo }\end{array}$ & $\begin{array}{l}\text { Bastnäsite } \\
\text { Mountain Pass }\end{array}$ & $\begin{array}{c}\text { Monazite and } \\
\text { xenotime in placer deposits }\end{array}$ \\
\hline REO grade $(\%)$ & 4.1 & 7.7 & 1.0 \\
\hline Recovery rate $(\%)$ & $50.0^{\mathrm{a}}$ & 90.0 & 75.0 \\
\hline Tonne mined/tonne REO & 49.0 & 14.4 & 133.0 \\
\hline Tonne mined/tonne REM & 59.0 & 17.4 & 160.2 \\
\hline Energy input (GJ/tonne REM) & 5.9 & 1.7 & 6.4 \\
\hline
\end{tabular}

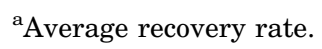


monazite concentrates obtained contain about $68 \%$ and $45 \%$ REO, respectively. The total recovery of rare earth from the primary ore is about $72 \%$; the remaining $28 \%$ is lost in the gangue. ${ }^{12}$ Thus, to obtain 1 tonne of REM, 2.46 tonnes of bastnäsite concentrate and 3.72 tonnes of monazite concentrate need to be further treated. For each tonne of $\mathrm{RE}$ concentrate obtained, about 0.40 tonnes of REM are lost in the gangue.

The REMs contained in bastnäsite are extracted by roasting with $98 \%$ sulfuric acid at $500^{\circ} \mathrm{C}$ in a rotary kiln. ${ }^{9}$ Monazite concentrate is alkali treated as explained in the Monazite by alkali treatment (Rhône-Poulenc) section. Roasting, mostly used for sulfidic sources of metals, is one of the most important and the most complex of all the pyrometallurgical unit operations. This process is carried out by heating the sulfides in air or in oxygen. A sulfide ore or concentrate is roasted to: (I) oxidize partially the sulfur content; (II) oxidize to sulfates, also regarded as sulfation roasting; and (III) remove completely sulfur by converting all sulfur to oxides. ${ }^{14}$ The theoretical heat required to roast 1 tonne of bastnäsite at $500^{\circ} \mathrm{C}$ can be calculated by doing an energy balance using Eq. (1):

$$
Q=m \cdot C_{\mathrm{p}} \cdot \Delta T
$$

where $m$ is the mass of bastnäsite in $\mathrm{kg} ; C_{\mathrm{p}}$ is the heat capacity at constant pressure of bastnäsite; $\Delta T$ is the change of temperature in the furnace in $\mathrm{K}$, from initial ambient temperature to $773 \mathrm{~K}$. The $C_{\mathrm{p}}$ of bastnäsite is calculated as the sum of the specific heat and the mass fraction of each of the chemical element of bastnäsite and is estimated to be $0.44 \mathrm{~kJ} /$ $\mathrm{kg} \mathrm{K} .^{23}$ The energy requirement doing this estimation is $0.20-0.27 \mathrm{GJ} /$ tonne of bastnäsite. Based on the fact that 2.46 tonnes of bastnäsite concentrate are needed to obtain 1 tonne of REM, the energy required for roasting is about $0.49-0.66 \mathrm{GJ} /$ tonne of REM. A more realistic estimate can be done using data of the typical heat use by a long lime rotary kiln, which reaches a similar temperature to that of bastnäsite roasting. A rotary kiln requires 6.09.2 GJ of heat and 0.06-0.09 GJ of electrical power to roast 1 tonne of lime. ${ }^{24}$ Using data for lime roasting, the total energy input for roasting 1 tonne of REM is between 6.06 GJ and 9.29 GJ.

By acid roasting RE mineral ores, the fluorocarbonate matrix is destroyed and REs are converted to their sulfates. The chemical reaction also generates hydrofluoric acid and carbonic acid. ${ }^{25}$

$$
\begin{aligned}
& 2 \mathrm{RECO}_{3} \mathrm{~F}+3 \mathrm{H}_{2} \mathrm{SO}_{4} \rightarrow \mathrm{RE}_{2}\left(\mathrm{SO}_{4}\right)_{3} \\
& +2 \mathrm{HF}+2 \mathrm{H}_{2} \mathrm{CO}_{3}
\end{aligned}
$$

$\mathrm{RE}$ sulfates are then precipitated as a double sodium sulfate by leaching with water and adding sodium chloride (solid liquid ratio 1:4). During dissolution, it is important to monitor temperature as the solubility of sulfates decreases with increasing temperature.

$$
\begin{aligned}
& 4 / 3 \mathrm{RE}_{2}\left(\mathrm{SO}_{4}\right)_{3}+12 \mathrm{H}_{2} \mathrm{O}+2 \mathrm{NaCl} \\
& \quad \rightarrow \mathrm{RE}_{2}\left(\mathrm{SO}_{4}\right)_{3} \cdot \mathrm{Na}_{2} \mathrm{SO}_{4} \cdot 12 \mathrm{H}_{2} \mathrm{O}+2 / 3 \mathrm{RECl}_{3}
\end{aligned}
$$

Then, rare metal sulfates are converted to hydroxides by digestion in a strong caustic solution. Hydroxides are subsequently dissolved in hydrochloric acid.

$$
\begin{gathered}
\mathrm{RE}_{2}\left(\mathrm{SO}_{4}\right)_{3} \cdot \mathrm{Na}_{2} \mathrm{SO}_{4} \cdot 12 \mathrm{H}_{2} \mathrm{O}+6 \mathrm{NaOH} \\
\rightarrow 2 \mathrm{RE}(\mathrm{OH})_{3}+4 \mathrm{Na}_{2} \mathrm{SO}_{4}+12 \mathrm{H}_{2} \mathrm{O} \\
\mathrm{RE}(\mathrm{OH})_{3}+3 \mathrm{HCl} \rightarrow \mathrm{RECl}_{3}+3 \mathrm{H}_{2} \mathrm{O}
\end{gathered}
$$

Once RE are in chloride form, they are separated

\begin{tabular}{|c|c|c|c|}
\hline & Chemical formula & Input (tonnes) & Output (tonnes) \\
\hline Bastnäsite & $\mathrm{RECO}_{3} \mathrm{~F}$ & 5.97 & 1.31 \\
\hline Sulfuric acid & $\mathrm{H}_{2} \mathrm{SO}_{4}$ & 4.41 & 0.97 \\
\hline Sodium chloride & $\mathrm{NaCl}$ & 12.32 & 11.52 \\
\hline Sodium hydroxide & $\mathrm{NaOH}$ & 1.64 & 0.36 \\
\hline Hydrochloric acid & $\mathrm{HCl}$ & 1.17 & 0.26 \\
\hline Water & $\mathrm{H}_{2} \mathrm{O}$ & 1.90 & 3.47 \\
\hline Hydrofluoric acid & $\mathrm{HF}$ & & 0.47 \\
\hline Sodium sulfate & $\mathrm{Na}_{2} \mathrm{SO}_{4}$ & & 3.03 \\
\hline RE sulfate & $\mathrm{RE}\left(\mathrm{SO}_{4}\right)_{3}$ & & 1.36 \\
\hline $\mathrm{RE}$ disulfate & $\mathrm{RE}_{2}\left(\mathrm{SO}_{4}\right)_{3} \cdot \mathrm{Na}_{2} \mathrm{SO}_{4} \cdot 12 \mathrm{H}_{2} \mathrm{O}$ & & 1.34 \\
\hline RE hydroxide & $\mathrm{RE}(\mathrm{OH})_{3}$ & & 0.40 \\
\hline $\mathrm{RE}$ chlorides & $\mathrm{RECl}_{3}$ & & 2.92 \\
\hline Total & & 27.41 & 27.41 \\
\hline
\end{tabular}
by solvent extraction. Table III shows the mass balance for the extraction of 1 tonne of REM as chlorides from bastnäsite based on the Bayan Obo process. From the 2.92 tonnes of RE chlorides generated, about $35 \%$ is generated as co-product during the dissolution of $\mathrm{RE}$ sulfates with sodium chloride

Table III. Mass balance of the extraction of 1 tonne of REM from Bayan Obo (China) 
and considered as lost. Ideally, the process only loses $20 \%$ of the RE input; however, if we consider the yields of the reactions are not $100 \%$ and the unreacted materials containing $\mathrm{RE}$ are not recovered, then almost $60 \%$ of REMs are lost.

Bastnäsite Using Molycorp Process Developed by Kruesi and Duker Kruesi and Duker of Molycorp (Greenwood Village, CO) developed another process to produce rare earth chlorides from bastnäsite. ${ }^{26}$ After the ore is initially crushed, ground, classified, and concentrated to increase the rare earth concentrations from $15 \%$ to $60 \%$, the bastnäsite concentrate undergoes an acid digestion using hydrochloric acid to produce several rare earth chlorides. In practice, bastnäsite concentrate is attacked in excess hydrochloric acid (1.8 tonne of hydrochloric acid per tonne of mineral ore) at $93^{\circ} \mathrm{C}$.

$$
\begin{aligned}
& \mathrm{RECO}_{3} \mathrm{~F}+9 \mathrm{HCl} \rightarrow \mathrm{REF}_{3}+2 \mathrm{RECl}_{3}+3 \mathrm{HCl} \\
& \quad+3 \mathrm{H}_{2} \mathrm{O}+3 \mathrm{CO}_{2}
\end{aligned}
$$

The resulting mixture is filtered to separate the slurry and the cake. The cake contains rare earths that are further digested with sodium hydroxide $(\mathrm{NaOH})$ to produce rare earth hydroxides. In the real-life process, 5 tonnes of caustic soda are added per tonne of bastnäsite concentrate.

$$
\mathrm{REF}_{3}+3 \mathrm{NaOH} \rightarrow \mathrm{RE}(\mathrm{OH})_{3}+3 \mathrm{NaF}
$$

The rare earth hydroxide cake is neutralized and purified by using hydrochloric acid $(\mathrm{HCl})$, converting the hydroxides to chlorides.

$$
\mathrm{RE}(\mathrm{OH})_{3}+3 \mathrm{HCl} \rightarrow \mathrm{RECl}_{3}+3 \mathrm{H}_{2} \mathrm{O}
$$

At this stage, small amounts of sodium hydroxide $(\mathrm{NaOH})$ and sulfuric acid $\left(\mathrm{H}_{2} \mathrm{SO}_{4}\right)$ are added to precipitate iron hydroxide $\left(\mathrm{Fe}(\mathrm{OH})_{3}\right)$ and lead sulfate $\left(\mathrm{PbSO}_{4}\right)$. Also, barium chloride $\left(\mathrm{BaCl}_{2}\right)$ is added to precipitate the excess sulfate and remove thorium from the ore. The resulting mix is filtered to remove the cake (contains most of the impurities), and the solution is concentrated by evaporation. The wastes generated by the process include a sodium fluoride $(\mathrm{NaF})$ filtrate, which is recovered for further processing, and filter cake, which is discarded. The recovery rate of REO is estimated to be $92 \%{ }^{9}$ Table IV shows the mass balance for the extraction of 1 tonne of REM as chlorides from bastnäsite following the Molycorp process. By this process, about $17 \%$ tonnes of $\mathrm{RE}$ are lost in unreacted bastnäsite, $\mathrm{RE}$ fluoride, and hydroxide.

The amount of heat required for the process is calculated using Eq. (1). Based on that, the process requires theoretically $0.03-0.04$ GJ of heat per tonne of bastnäsite.

Bastnäsite Using Goldschmidt Process The Goldschmidt process is a direct chlorination at a high temperature $\left(1,200^{\circ} \mathrm{C}\right)$ used to obtain an anhydrous $\mathrm{RE}$ trichloride suited for the production of RE metals directly from bastnäsite ore. In the furnace, $\mathrm{RE}$ fluorocarbons are converted to chlorides by gaseous chlorine. The RE chlorides are collected in the melt chamber as a nonvolatile fluid melt. The main reaction is as follows:

$$
\begin{aligned}
& 3 \mathrm{RECO}_{3} \mathrm{~F}+3 \mathrm{Cl}_{2} \rightarrow \mathrm{REF}_{3}+2 \mathrm{RECl}_{3} \\
& \quad+3 / 2 \mathrm{O}_{2}+3 \mathrm{CO}_{2}
\end{aligned}
$$

In practice, the amount of chlorine input is two times the theoretically calculated (0.9-1 tonnes/ tonne of $\mathrm{RE}$ chlorine). The recovery rate of rare earths is $97 \%$. For each tonne of RE in chlorides, the process generates 0.50 tonnes of $\mathrm{RE}$ as fluorides, which can be further processed following the Kruesi and Duker method (see the "Bastnäsite Using Molycorp Process Developed by Kruesi and Duker" section) to obtain additional product. Table $\mathrm{V}$ shows the mass balance of the extraction of 1 tonne of $\mathrm{RE}$ as chlorides using the Goldschmidt process.

\begin{tabular}{|c|c|c|c|}
\hline & Chemical formula & Input (tonnes) & Output (tonnes) \\
\hline Bastnäsite & $\mathrm{RECO}_{3} \mathrm{~F}$ & 1.95 & 0.16 \\
\hline Hydrochloric acid & $\mathrm{HCl}$ & 1.35 & 0.44 \\
\hline Sodium hydroxide & $\mathrm{NaOH}$ & 0.33 & 0.03 \\
\hline $\mathrm{RE}$ fluorides & $\mathrm{REF}_{3}$ & & 0.08 \\
\hline RE hydroxides & $\mathrm{RE}(\mathrm{OH})_{3}$ & & 0.03 \\
\hline Water & $\mathrm{H}_{2} \mathrm{O}$ & & 0.29 \\
\hline Sodium fluoride & $\mathrm{NaF}$ & & 0.32 \\
\hline Carbon dioxide & $\mathrm{CO}_{2}$ & & 0.40 \\
\hline $\mathrm{RE}$ chlorides & $\mathrm{RECl}_{3}$ & & 1.89 \\
\hline Total & & 3.63 & 3.63 \\
\hline
\end{tabular}

The theoretical heat required by the furnace is about $0.94-1.21 \mathrm{GJ} /$ tonne of $\mathrm{RE}$ contained in bastnäsite whereas the energy use in real processes is 1.44-2.16 GJ/tonne RE chlorides. ${ }^{9}$ Thus, to obtain

Table IV. Mass balance of the extraction of 1 tonne of REM using Molycorp process 
1 tonne of REE from bastnäsite in Mountain Pass, between 4.26 GJ and 6.32 GJ are needed.

Baotau Concentrates by Direct Chlorination In China, Baotau concentrates (mainly bastnäsite and monazite) have also been directly chlorinated in the presence of carbon at high temperature following a chlorination process that is similar to Goldschmidt process:

$$
\begin{aligned}
& 3 \mathrm{RECO}_{3} \mathrm{~F}+3 \mathrm{Cl}_{2} \rightarrow \mathrm{REF}_{3}+2 \mathrm{RECl}_{3} \\
& \quad+3 / 2 \mathrm{O}_{2}+3 \mathrm{CO}_{2}
\end{aligned}
$$

Concentrates are first mixed with Charcoal (ratio 1:0.065-0.07) and pressed into briquettes that are dried at $120-140^{\circ} \mathrm{C}$. Then, briquettes are chlorinated in a graphite reactor at $950-1,100^{\circ} \mathrm{C}$. The chlorine consumption for this process is slightly lower than the Goldschmidt process, resulting in 0.84 tonnes/tonne of $\mathrm{RE}$ chlorides, and the recovery rate of $\mathrm{RE}$ is $91 \% .^{9} \mathrm{As}$ commented in the previous section, $\mathrm{RE}$ fluorides can be further processed to $\mathrm{RE}$ chlorides by digestion with sodium hydroxide $(\mathrm{NaOH})$ and then neutralized using hydrochloric acid $(\mathrm{HCl})$ (see "Bastnäsite Using Molycorp Process Developed by Kruesi and Duker" section). Table VI shows the mass balance of the extraction of $\mathrm{RE}$ using Goldschmidt process.

The theoretical heat required by the furnace is about $0.50-0.67 \mathrm{GJ} /$ tonne of ore. In real processes, the energy consumption is $3.6 \mathrm{GJ} /$ tonne of $\mathrm{RE}$ chlorides. Thus, 6.8 GJ of energy are required to obtain 1 tonne of REE.
Monazite by Alkali Treatment (Rhône-Poulenc at present Solvay-Rhodia (Brussels, Belgium)) The first step to recover rare earths and remove thorium from monazite is to apply to the mineral an acid or alkali treatment. The acid treatment uses sulfuric acid $\left(\mathrm{H}_{2} \mathrm{SO}_{4}\right)$ to precipitate double sulfates and later recover rare earths from thorium by solvent extraction. Although this process was extensively used in the United States, it is no longer in commercial use, and the current process used is the alkali treatment process developed by Rhône-Poulenc using caustic soda $(\mathrm{NaOH})$. By the addition of caustic soda, REs are precipitated in the form of hydroxides as a cake and trisodium phosphate $\left(\mathrm{Na}_{3} \mathrm{PO}_{4}\right)$ is generated as by-product. In the usual industrial practice, monazite is attacked with a 60 $70 \%$ sodium hydroxide solution at $140-150^{\circ} \mathrm{C} .^{27}$

$$
\mathrm{REPO}_{4}+3 \mathrm{NaOH} \rightarrow \mathrm{RE}(\mathrm{OH})_{3}+\mathrm{Na}_{3} \mathrm{PO}_{4}
$$

Alkali digestion can also be performed in one step, which enables about 50\% savings in caustic soda consumption or at $170^{\circ} \mathrm{C}$ under a pressure of several atmospheres. The resulting rare earth hydroxide cake is dissolved in nitric acid.

$$
\mathrm{RE}(\mathrm{OH})_{3}+3 \mathrm{HNO}_{3} \rightarrow \mathrm{RE}\left(\mathrm{NO}_{3}\right)_{3} \cdot 3 \mathrm{H}_{2} \mathrm{O}
$$

The process recovers $90 \%$ of the $\mathrm{RE}$ contained in monazite; 2.21 tonnes of monazite are needed to

\begin{tabular}{|c|c|c|c|}
\hline & Chemical formula & Input (tonnes) & Output (tonnes) \\
\hline Roctnöcito & $\mathrm{RECO}_{3} \mathrm{~F}$ & 2.56 & 0.08 \\
\hline Unlorine & $\mathrm{Cl}_{2}$ & 2.44 & 1.55 \\
\hline RE fluorides & $\mathrm{REF}_{3}$ & & 0.74 \\
\hline RE chlorides & $\mathrm{RECl}_{3}$ & & 1.89 \\
\hline Oxygen & $\mathrm{O}_{2}$ & & 0.20 \\
\hline Carbon dioxide & $\mathrm{CO}_{2}$ & & 0.55 \\
\hline Total & & 5.00 & 5.00 \\
\hline
\end{tabular}
obtain 1 tonne of REM. Table VII shows the mass balance of the extraction of RE using the alkali

\begin{tabular}{|c|c|c|c|}
\hline & Chemical formula & Input (tonnes) & Output (tonnes) \\
\hline Bastnäsite & $\mathrm{RECO}_{3} \mathrm{~F}$ & 2.73 & 0.25 \\
\hline Chlorine & $\mathrm{Cl}_{2}$ & 1.58 & 0.70 \\
\hline RE fluorides & $\mathrm{REF}_{3}$ & & 0.74 \\
\hline RE chlorides & $\mathrm{RECl}_{3}$ & & 1.89 \\
\hline Oxygen & $\mathrm{O}_{2}$ & & 0.20 \\
\hline Carbon dioxide & $\mathrm{CO}_{2}$ & & 0.55 \\
\hline Total & & 4.32 & 4.32 \\
\hline
\end{tabular}

Table V. Mass balance of the extraction of 1 tonne of REM using Goldschmidt process

Table VI. Mass balance of the extraction of 1 tonne of REM using direct chlorination process 
Table VII. Mass balance of the extraction of 1 tonne of REM using direct alkali treatment developed by Rhône-Poulenc

\begin{tabular}{|c|c|c|c|}
\hline & Chemical formula & Input (tonnes) & Output (tonnes) \\
\hline RE phosphate & $\mathrm{REPO}_{4}$ & 2.21 & 0.22 \\
\hline Sodium hydroxide & $\mathrm{NaOH}$ & 1.23 & 0.12 \\
\hline Nitric acid & $\mathrm{HNO}_{3}$ & 1.94 & 0.37 \\
\hline RE hydroxides & $\mathrm{RE}(\mathrm{OH})_{3}$ & & 0.16 \\
\hline Trisodium phosphate & $\mathrm{Na}_{3} \mathrm{PO}_{4}$ & & 1.52 \\
\hline RE nitrate & $\mathrm{RE}\left(\mathrm{NO}_{3}\right)_{3}$ & & 2.55 \\
\hline Water & $\mathrm{H}_{2} \mathrm{O}$ & & 0.45 \\
\hline Total & & 5.39 & 5.39 \\
\hline
\end{tabular}

Table VIII. Mass balance of the extraction of 1 tonne of REM using acid treatment

\begin{tabular}{lccc}
\hline & Chemical Formula & Input (tonnes) & Output (tonnes) \\
\cline { 2 - 2 } RE phosphate & $\mathrm{REPO}_{4}$ & 2.92 & 0.44 \\
Sulfuric acid & $\mathrm{H}_{2} \mathrm{SO}_{4}$ & 7.58 & 7.33 \\
Oxalic acid & $\mathrm{H}_{2} \mathrm{C}_{2} \mathrm{O}_{4}$ & 1.83 & 0.51 \\
Phosphoric acid & $\mathrm{H}_{3} \mathrm{PO}_{4}$ & & 1.13 \\
RE sulfate & $\mathrm{RE}_{2}\left(\mathrm{SO}_{4}\right)_{3}$ & & 0.46 \\
RE oxalate & $\mathrm{RE}_{2}\left(\mathrm{C}_{2} \mathrm{O}_{4}\right)_{3}$ & & 0.37 \\
RE oxides & $\mathrm{RE}_{2} \mathrm{O}_{3}$ & & 1.20 \\
Carbon dioxide & $\mathrm{CO}_{2}$ & & 0.55 \\
Carbon monoxide & $\mathrm{CO}$ & & 0.35 \\
Total & & 12.33 & 12.33 \\
\hline
\end{tabular}

treatment process. The amount of heat required theoretically is $0.06 \mathrm{GJ} /$ tonne of monazite.

Xenotime Xenotime is first milled to a required particle size and then roasted in a furnace. Then, it undergoes a digestion with concentrated sulfuric acid $(93 \%)$ in an acid to a solid weight ratio of 2.6:1 at $250-300^{\circ} \mathrm{C}$ for $1-2 \mathrm{~h} .{ }^{28}$ Leaching is uneconomical for concentrates containing less than $10 \%$ xenotime. The rare earth phosphates are converted to watersoluble sulfates, and phosphoric acid is generated as a by-product of the following reaction:

$$
2 \mathrm{REPO}_{4}+3 \mathrm{H}_{2} \mathrm{SO}_{4} \rightarrow \mathrm{RE}_{2}\left(\mathrm{SO}_{4}\right)_{3}+2 \mathrm{H}_{3} \mathrm{PO}_{4}
$$

By sulfuric acid digestion, the RE phosphate is converted to the water-soluble sulfate. Cold water is used as the leachant for better recovery. Oxalic acid $\left(\mathrm{H}_{2} \mathrm{C}_{2} \mathrm{O}_{4}\right)$ is added to the $\mathrm{RE}$ sulfate solution to precipitate $\mathrm{RE}$ oxalate.

$$
\mathrm{RE}_{2}\left(\mathrm{SO}_{4}\right)_{3}+3 \mathrm{H}_{2} \mathrm{C}_{2} \mathrm{O}_{4} \rightarrow \mathrm{RE}_{2}\left(\mathrm{C}_{2} \mathrm{O}_{4}\right)_{3}+3 \mathrm{H}_{2} \mathrm{SO}_{4}
$$

The final stage is the calcination of $\mathrm{RE}$ oxalate to the following oxide:

$$
\mathrm{RE}_{2}\left(\mathrm{C}_{2} \mathrm{O}_{4}\right)_{3} \rightarrow \mathrm{RE}_{2} \mathrm{O}_{3}+3 \mathrm{CO}_{2}+3 \mathrm{CO}
$$

The recovery of rare earths by processes such as double-sulfate precipitation is not possible because yttrium and the heavy rare earth sulfates are quite soluble. The sulfate solution is directly taken for separation. About $80 \%$ to $90 \%$ of RE are solubilized. For our calculations, we use an average recovery ratio of $85 \%$. Thus, to obtain 1 tonne of REE, almost 3 tonnes of RE phosphates are needed. Table VIII shows the mass balance of the extraction of RE using the acid treatment process. The amount of heat required theoretically is $0.13-0.15 \mathrm{GJ} /$ tonne of xenotime.

In an alternative process, the fine-ground xenotime is treated by fusing it with molten caustic soda at $400^{\circ} \mathrm{C}{ }^{29}$ or by mixing it with sodium carbonate and roasting at $900^{\circ} \mathrm{C}$ for several hours. ${ }^{30}$ After leaching out the phosphates, the hydroxide residue is dissolved in a minimum amount of hydrochloric acid and is filtered from impurities such as silica, cassiterite, etc. The rare earths are recovered by precipitation as oxalates.

\section{Separation of RE Elements}

The separation of rare earth elements poses many difficulties due to the great similarity of their chemical properties. Various separation procedures can be used: fractional crystallization, fractional precipitation, ion exchange, and solvent extraction. By fractional crystallization, one or more rare earths in a mixture are precipitated by changing the salt concentrations in solution through evaporation or temperature control. Fractional precipitation 
involves adding a precipitating agent to selectively remove a metal from solution. Ion exchange consists of an exchange of ions between two electrolytes or between an electrolyte and an organic complex. It is usually used to produce highly pure rare earths in relatively small quantities and is not suitable for high volume production. Among all these procedures, the most widely used is solvent extraction.

Solvent extraction uses the ability of metals to form stable complexes with organic molecules that can be later separated by gravity. The separation of a substance occurs from one organic phase (phase 1) into a water phase (phase 2). Liquid-liquid extraction is characterized by distribution coefficients, which vary greatly from element to element. For any element, the distribution coefficient is defined as its concentration in the organic phase divided by its concentration in the aqueous phase. Equation (2) shows how it is calculated for substance A:

$$
D_{\mathrm{A}}=\frac{C_{\mathrm{A} 1}}{C_{\mathrm{A} 2}}
$$

For substance B similarly distributed as A, we can define the distribution coefficient $D_{\mathrm{B}} . D_{\mathrm{A}}$ and $D_{\mathrm{B}}$ provide information about which of the two substances concentrates preferably in each phase. The ratio of the distribution coefficients $D_{\mathrm{A}}$ and $D_{\mathrm{B}}$ is called separation factor $\left(\alpha_{\mathrm{B}}^{\mathrm{A}}\right)$, defined by Eq. (3) as follows:

$$
\alpha_{\mathrm{B}}^{\mathrm{A}}=\frac{D_{\mathrm{A}}}{D_{\mathrm{B}}}
$$

Separation between substance A and B happens when $\alpha_{\mathrm{B}}^{\mathrm{A}}$ is either much more or $<1$. No separation is achieved when the value is similar to 1 . Distribution coefficients and separation factor depend on the type of extractant. The selection of the extractants depends on the chemical form of rare earths: chloride, nitrates, sulfates, or oxides (see supporting information). The extractants commercially used most often for rare earth separation are di-2-ethyl-hexylphosphoric acid (HDEHP) for RE chlorides and sulfates, and tri- $n$-butyl phosphate (TBP) for RE nitrates. Other extractants used are 2-ethyl-hexyl-2ethyl-hexyl-phosphoric acid (EHEHPA), versatic acid, versatic 10, and Aliquat 336. The extractant is usually dissolved in a suitable solvent to ensure good contact with the aqueous phase. A modifier is frequently added to the organic phase to improve the hydrodynamics of the system.

One of the first extractants used was TBP. TBP is the most effective extractant for nitrates of rare earths such as those obtained from monazite using the Rhône-Poulenc process. The liquid-liquid extraction process can be represented by the following reaction:

$$
\begin{aligned}
& {\left[\mathrm{RE}\left(\mathrm{NO}_{3}\right)_{3} \cdot 3 \mathrm{H}_{2} \mathrm{O}\right]_{\mathrm{aq}}+3[\mathrm{TBP}]_{\mathrm{org}}} \\
& \quad \rightarrow\left[\mathrm{RE}\left(\mathrm{NO}_{3}\right)_{3} \cdot \mathrm{TBP}_{3}\right]_{\mathrm{org}}+3 \mathrm{H}_{2} \mathrm{O}
\end{aligned}
$$

The results obtained by Peppard et al. ${ }^{31,32}$ showed that TBP is an effective extractant to separate trivalent rare earths from one another. Several studies using TBP obtained $98 \%$ pure gadolinium oxide $\left(\mathrm{Gd}_{2} \mathrm{O}_{3}\right)$ and $98 \%$ pure samarium oxide $\left(\mathrm{Sm}_{2} \mathrm{O}_{3}\right)$; the separation beyond terbium is difficult. ${ }^{33}$ The separation factors for various rare earth pairs using TBP are given in the supporting information.

Another extractant frequently used is HDEHP (or $\mathrm{HA}$ in reaction nomenclature). HDEHP can extract REO from a variety of aqueous media including nitrate, sulfate, and chloride, even though it is considered to extract better from chloride medium. HDEHP is a typical cation exchange extractant, which displaces a hydrogen ion from the extractant by the extracted metal resulting in the formation of an electrically neutral organic soluble complex. The extraction can be represented by the following reaction:

$$
\left[\mathrm{RE}^{3+}\right]_{\mathrm{aq}}+\left[3(\mathrm{HA})_{2}\right]_{\mathrm{org}} \rightarrow\left[\mathrm{RE}\left(\mathrm{HA}_{2}\right)_{3}\right]_{\mathrm{org}}+3\left[\mathrm{H}^{+}\right]_{\mathrm{aq}}
$$

The extraction yield increases with the increase in the atomic number of the metal. HDEHP gives good separation factors for all rare earth elements. The average separation between each rare earth is $\sim 2.5$, as illustrated in the supporting information.

The extractant EHEHPA in kerosene was also reported as useful for the extraction of rare earth chlorides. The extraction yield also increases with atomic number but is lower than for HDEHP. EHEHPA has higher separation factors and thus is more preferred and especially advantageous for the separation of heavy from light rare earths. Separation factors for EHEHPA are also given in the supporting information.

In industry, a first solvent extraction using chloride medium is done to separate REMs into subgroups. Then, the metals are separated into individual elements during a second solvent extraction process using a nitrate medium. Subgroups can be divided as light ( $\mathrm{La}, \mathrm{Ce}, \mathrm{Pr}, \mathrm{Nd}$, etc.), middle (Sm, Eu, Gd, etc.) and heavy (Tb, Dy, Ho, Er, $\mathrm{Tm}, \mathrm{Yb}, \mathrm{Lu}, \mathrm{Y})$ rare earths. ${ }^{34}$ In both solvent extraction processes, many repetitions of a single separation operation are necessary. The number of stages increases with the increase in purity of each individual rare earth produced. A minimum of 50 mixer-settler stages per stream is required to obtain a metal with a purity of four or five nines. For instance, Rhône-Poulenc which produces all rare earth with purities of $>99.999 \%$ operates more than 1,000 separation units, some difficult separations alone requiring 60 of such units. ${ }^{15}$

Most of the solvent extraction work provides information about the concentration of solvent but does not provide information about the solvent-tofeed ratio necessary to perform a material balance for the process and to estimate the amount of solvent required for obtaining each REM. As result, 
and considering that the actual practices by industry remain secret, we only can provide rough estimates of the amount of solvent and electricity used based on information from other processes. In most processes, the solvent-to-feed ratio is normally $3: 1$. Assuming a recovery yield of $90-95 \%$, about $7.02-$ 7.41 tonnes of TBP dissolved in kerosene are needed for the extraction of 1 tonne of REM. ${ }^{35}$ For instance, 7.04 tonnes of kerosene containing TBP are used to extract 1 tonne of yttrium oxide. ${ }^{16}$

REMs are extracted by using mixer settlers that first mix the phases together then allow the phases to separate by gravity during a settling stage, and finally, the metals are stripped out. The energy input required for this processes is basically the electricity required for pumping. The amount of electricity required to obtain 1 tonne of REM can be estimated using data for the extraction of yttrium oxide $\left(\mathrm{Y}_{2} \mathrm{O}_{3}\right)$ and uranium. The production of 1 tonne of yttrium oxide $\left(\mathrm{Y}_{2} \mathrm{O}_{3}\right)$ from uranium residues consumes $22 \mathrm{GJ}$ for the solvent extraction and 0.7 GJ for stripping. ${ }^{16}$ The electricity inputs required for the extraction and stripping of 1 tonne of uranium are 0.3 GJ and 0.01 GJ per stage, assuming that the process requires at least 50 repetitions, the electricity input is $15.25 \mathrm{GJ}$ and 0.36 GJ, respectively. ${ }^{36}$ Thus, about $15.60-22.7$ GJ of electricity is required to extract 1 tonne of an individual REM.

\section{Reduction of Individual REMs}

Once all REMs are separated by solvent extraction, there are two methods to obtain pure REM: metallothermic reduction and electrolysis. The metallothermic reduction of $\mathrm{RE}$ oxides, anhydrous $\mathrm{RE}$ chlorides, and fluorides produces high-purity REM. It can be also used at a high temperature to produce RE mixtures with specific compositions that cannot be obtained by fused salt electrolysis. ${ }^{9}$ The reaction of reduction can be represented as follows:

$$
M X_{n}+i R \rightarrow M+i R X_{n / i}
$$

where $M$ is the metal to recover; $X$ is oxygen, fluorine, or chlorine; and $R$ is the reducing agent that can be hydrogen, carbon, or other metals such as lithium, sodium, potassium, magnesium, calcium, or aluminum.

The theoretical energy required to reduce any metal is the sum of the latent and sensible heats. The latent heat is the internal energy associated with the phase of a system. The sensible heat is the heat exchanged by a substance. ${ }^{37}$ The sensible heat of a substance can be calculated using Eq. (4).

$$
Q_{\text {sensible }}=m \times C_{\mathrm{p}} \times \Delta T
$$

where $m$ is the mass, $C_{\mathrm{p}}$ is the specific heat capacity, and $\Delta T$ is the change in temperature. The specific heat is defined as the energy required to raise the temperature of a unit mass of a substance by one degree (usually Celsius or Kelvin) as the pressure remains constant.

The amount of energy absorbed or released during a phase-change process is called latent heat. The latent heat of fusion is the heat supplied to a solid body at the melting point. ${ }^{37}$ The standard enthalpy of formation is the enthalpy change when 1 mole of a pure substance is formed from its elements.

$$
Q_{\text {latent }}=m \times \Delta H_{\mathrm{f}}
$$

where $Q$ is the amount of energy released or absorbed during the change of phase of the substance $(\mathrm{kJ}), m$ is the mass of the substance $(\mathrm{kg})$, and $\Delta H_{\mathrm{f}}$ is the specific latent heat of fusion for a particular substance $(\mathrm{kJ} / \mathrm{kg})$. The enthalpy of fusion is the change in enthalpy resulting from heating one mol of a substance to change its state from a solid to a liquid. The temperature at which this occurs is the melting point. For instance, the reduction of 1 tonne of cerium requires a total of $0.334 \mathrm{GJ}$ : $0.147 \mathrm{GJ}$ for melting and 0.187 GJ for phase change. The supporting information includes the values for specific heats and the enthalpy of fusion for each REM.

The second method to obtain pure REMs is electrolysis. By electrolysis, REMs are separated when electrical energy is applied in an electrolytic cell. The most common types of processes using electrolysis are electrowinning and electrorefining. Electrowinning refers to the reduction of metals from solution to the solid state. It is used to recover metals in aqueous solution, usually as the result of an ore having undergone one or more hydrometallurgical processes. The two electrodes are placed in a solution (electrolyte) containing metal ions, and an electric current is passed between them. The metal of interest is plated onto the cathode, while the anode is an inert electrical conductor. Electrorefining starts with impure metal, oxidizes it into solution, and then reduces it back to the pure solid state. It is used to dissolve an impure metallic anode (typically from a smelting process) and produce a high-purity cathode. Fused salt electrolysis is another electrometallurgical process whereby the valuable metal has been dissolved into a molten salt that acts as the electrolyte, and the valuable metal collects on the cathode of the cell. It is conducted at temperatures sufficient to keep both the electrolyte and the metal being produced in the molten state. In electrolysis, the theoretical specific power consumption can be calculated as a function of cell voltage by combining Joule's law and Faraday's law. ${ }^{38}$

$$
\frac{P_{t}}{m}=\frac{V F z}{M} \times \frac{1 \mathrm{~h}}{3,600 \mathrm{~s}}
$$

where $P$ is the power consumed (kWh), $m$ is the mass of deposited metal $(\mathrm{kg}), V$ is the cell voltage (V), $\mathrm{F}$ is Faraday's constant $(96,485 \mathrm{C} / \mathrm{mol}), z$ is the valence of the deposited ion (for $\mathrm{RE} z$ equals to 3 ), $M$ is the atomic weight $(\mathrm{g} / \mathrm{mol})$, and $t$ is the plating time in hours. Equation (6) can be redefined for a 
certain amount of metal to be deposited and using the number of moles $(n)$ instead of the mass of the deposited metal $(m)$ and the atomic weight $(M)$ leading to Eq. (7).

$$
P=n V F z
$$

In the electrolysis of rare earth chlorides $\left(\mathrm{RECl}_{3}\right)$, the valence of the deposited ion is normally three. The theoretical voltage is about $4 \mathrm{~V}$, although in real life the net voltage is usually greater than the theoretical estimation due to power losses. The efficiency of the cell must be also considered in the estimation. Shedd et al. ${ }^{39}$ estimated the average voltage to be $8.5 \mathrm{~V}$ and the current efficiency at $37 \%$. The energy use to obtain 1 tonne of an individual REM varies from 38 GJ to 48 GJ, expect from scandium and yttrium, which require 148 GJ and $75 \mathrm{GJ} /$ tonne, respectively. Electrolysis is also used to produce mischmetal containing mainly lanthanum, cerium, neodymium, and praseodymium. For a mixture of $\mathrm{RE}$ obtained from a treated bastnäsite with a molecular mass of $120 \mathrm{~g} / \mathrm{mol}$, the power consumed is $55.45 \mathrm{GJ} /$ tonne. This value is on the range of 48.96-57.60 GJ/tonne estimated by other authors. ${ }^{9}$ Habashi estimated an energy consumption of 36-54 GJ/tonne of mischmetal (a combination of lanthanum, cerium, praseodymium, neodymium, and samarium). ${ }^{8}$ The supporting information includes thermodynamic data and calculations done to estimate the energy required to recover 1 tonne of REM by reduction and electrolysis, as well as a typical analysis of mischmetal obtained by the electrolysis of RE.

\section{RESULTS AND CONCLUSION}

The objective of this work is to provide a first estimate of the material and energy requirements for the production of REMs to aid scientists in evaluating the ever-increasing use in today's technologies. Because company data are generally confidential and off limits, these estimates are based on process descriptions and thermodynamics. Table IX summarizes the material and energy requirement for the extraction of REM from different mineral ores and their recovery rates. As shown in the table,

Table IX. Material and energy requirement for the production of 1 tonne of REE

\begin{tabular}{|c|c|c|c|}
\hline & $\begin{array}{c}\text { Recovery } \\
\text { rate REM }(\%)\end{array}$ & $\begin{array}{c}\text { Material } \\
\text { input (tonnes) }\end{array}$ & $\begin{array}{c}\text { Energy } \\
\text { input (GJ) }\end{array}$ \\
\hline \multicolumn{4}{|l|}{ Mlıneral processing } \\
\hline \multicolumn{4}{|l|}{ Mining } \\
\hline Bastnäsite Bayan Obo & 50 & 60.2 mined ore & 6 \\
\hline Bastnäsite Mountain Pass & 90 & 17.4 mined ore & 1.7 \\
\hline Monazite/xenotime & 75 & 160.2 mined ore & 6.4 \\
\hline \multicolumn{4}{|l|}{ Beneficiation } \\
\hline Extraction 1: Bayan Obo mineral & 72 & $\begin{array}{l}\quad 5.97 \text { bastnäsite } \\
4.41 \text { sulfuric acid } \\
12.32 \text { sodium chloride } \\
1.64 \text { sodium hydroxide } \\
1.17 \text { hydrochloric acid } \\
1.90 \text { water }\end{array}$ & $6.06-9.29$ \\
\hline Extraction 2: Bastnäsite by Kruesi and Duker & 92 & $\begin{array}{c}1.95 \text { bastnäsite } \\
1.35 \text { hydrochloric acid } \\
0.33 \text { sodium hydroxide }\end{array}$ & $0.03-0.04$ \\
\hline Extraction 3: Bastnäsite by Goldschmidt process & 97 & $\begin{array}{l}2.56 \text { bastnäsite } \\
2.44 \text { chlorine }\end{array}$ & $4.26-6.32$ \\
\hline Extraction 4: Baotau concentrates & 91 & $\begin{array}{l}2.73 \text { bastnäsite } \\
1.58 \text { chlorine }\end{array}$ & 6.80 \\
\hline Extraction 5: Monazite by Rhône-Poulenc & 90 & $\begin{array}{l}2.21 \text { monazite } \\
1.23 \text { sodium hydroxide } \\
1.94 \text { nitric acid }\end{array}$ & 0.06 \\
\hline Extraction 6: Xenotime & $80-90$ & $\begin{array}{l}\quad 2.92 \text { xenotime } \\
7.58 \text { sulfuric acid } \\
1.83 \text { oxalic acid }\end{array}$ & $0.13-0.15$ \\
\hline \multicolumn{4}{|l|}{ Separation } \\
\hline Solvent extraction & $90-95$ & 7.02-7.40 TBP & $15.60-22.70$ \\
\hline \multicolumn{4}{|l|}{ Reduction } \\
\hline Metallothermic reduction & & - & $0.33 *$ \\
\hline Electrolysis & & - & $38-48$ \\
\hline
\end{tabular}

* Theoretical estimate for Cerium. For the rest of REM see Table S5 of supporting information 
the energy required for mining $\mathrm{RE}$ depends on the ore grade and on the recovery yield, which vary from 50\% to $90 \%$ depending on the facility; Mountain Pass has the highest recovery rate registered. The recovery of RE from placer deposits requires the extraction of greater amount of ores, 10 times that of Mountain Pass, but it has a similar energy consumption $(0.4 \mathrm{GJ} /$ tonne of REM higher) to that the mining of Bastnäsite Ore in Bayan Obo.

The process for the beneficiation of REM highly depends on the chemical form of $\mathrm{RE}$ in the mineral ore. Bastnäsite beneficiated using chlorine has higher recovery yield (91-97\%) and a lower energy consumption (0.03-6.80 GJ/tonne of REM) than using sulfuric acid (with $72 \%$ recovery yield and 6.06-9.29 GJ/tonne of REM), especially because for chlorination processes, the roasting of the concentrate is not required. The beneficiation of REM is the stage with the highest material input requirement, specifically the beneficiation of bastnäsite from Bayan Obo, which requires 21.44 tonnes of reactants compared to that of xenotime and monazite, which require 9.14 tonnes and 3.18 tonnes, respectively. The material and energy requirement for separating each REM by solvent extraction are rough estimates based on other process description and require further research. $\mathrm{RE}$ can be reduced by metallothermic reduction or electrolysis. The energy requirement for metallothermic reduction is also a theoretical estimate, and less realistic that the energy use for electrolysis that is based on process data given for the electrolysis of other metals.

In the light of these preliminary results, we can say that the energy requirement for beneficiation depends on the type of mineral ore; for instance, the production of 1 tonne of REM from bastnäsite in Bayan Obo requires a minimum energy input of 12.06 GJ, whereas 1 tonne of REM from Mountain Pass needs 1.73 GJ. The most energy-intensive stages in the production of REM are the separation of each RE by solvent extraction (15.60-22.70 GJ/ tonne of REM) and the reduction of each RE, whose energy consumption varies from 38 to 48 GJ. For instance, the electrolysis of 1 tonne of REM from Mountain Pass, which contains mainly cerium, lanthanum, and neodymium, as described in the supporting information, requires 47.34 GJ of energy. In overall, the mineral processing and reduction of 1 tonne of an individual REM have an average energy intensity of $58.51 \mathrm{GJ}$, which is similar to that of manganese $(58 \mathrm{GJ} /$ tonne) but higher than base metals like iron (28 GJ/tonne) and lead (31 GJ/tonne). ${ }^{14}$

Performing detailed material balances also helps to identify where further amounts of REM are generated, which, if exploited, can provide additional sources of REMs. REMs are lost mainly as unreacted minerals and by-products as RE fluorites, sulfates, and chlorides during beneficiation. The greatest loss occurs mainly during mining (up to $50 \%$ ) and beneficiation (up to 28\%) in Bayan Obo. The recovery of those REM depends on the type and chemical form of the gangue minerals and reactants they end up with. Information about the composition of gangue minerals and tailings is hard if not impossible to find; thus, it is not possible to provide an educated estimate of the amount of REM potentially recoverable. The production of REM from Mountain Pass is a good example to show how increasing the recovery yield from existing mines and during beneficiation helped increase the amount of REM production. Improving recovery yields of REM involves a significant reengineering of extraction and refining processes, originally designed to concentrate and recover iron ores rather than rare earths considered traditionally "contaminants" of iron.

\section{ACKNOWLEDGEMENTS}

This work has been possible thanks to the EU collaborative project PROSUITE under the seventh framework program and the Marie Curie Fellowship (FP7-PLEOPLE-2010-IEF 272206).

\section{ELECTRONIC SUPPLEMENTARY MATERIAL}

The online version of this article (doi:10.1007/ s11837-013-0719-8) contains supplementary material, which is available to authorized users.

\section{REFERENCES}

1. M. Buchert, D. Schueler, and D. Bleher, Sustainable Innovation and Technology Transfer Industrial Sector Studies (Nairobi: United Nations Environment Program [UNEP], 2009).

2. U.S. National Research Council and Committee on Critical Mineral Impacts of the U.S. Economy, Minerals, Critical Minerals and the US Economy (Washington, D.C.: National Academy Press, 2008).

3. European Commission, Annex $V$ to the Report of the Ad-hoc Working Group on Defining Critical Raw Materials (Brussels: European Commission, 2010), p. 220.

4. European Commission, Critical Raw Materials for the European Union (Brussels: European Commission, 2010).

5. L. Erdmann and T.E. Graedel, Environ. Sci. Technol. 45, 7620 (2011).

6. J. Gambogi, Mineral Commodity Summaries: Rare Earths (Washington, D.C.: United States Geological Survey, 2013), pp. 128-129.

7. L. Talens Peiró, G. Villalba Méndez, and R.U. Ayres, Environ. Sci. Technol. 47, 2939 (2013).

8. F. Habashi, eds., Handbook of Extractive Metallurgy (Weinheim: Wiley-VCH, 1997).

9. C.K. Gupta and N. Krishnamurthy, Extractive Metallurgy of Rare Earths (Boca Raton: CRC Press, 2005).

10. A.V. Naumov, Russian J. Non-Ferrous Met. 49, 24 (2008).

11. British Geological Survey, Mineral Profile: Rare Earth Elements (Nottingham: British Geological Survey, 2011), pp. $1-45$.

12. C.K. Gupta and N. Krishnamurthy, Int. Mater. Rev. 37, 197 (1992).

13. C.A. Hampel, eds., Rare Metals Handbook, 2nd ed. (Malabar: Robert E. Krieger Publishing Co. Inc., 1971), p. 715.

14. C.K. Gupta, Chemical Metallurgy: Principles and Practice (Weinheim: Wiley-VCH Verlag, 2003), p. 831. 
15. I. McGill, Rare Earth Elements, Ullmann's Encyclopedia of Industrial Chemistry (2000).

16. Battelle Columbus Laboratories, Energy Use Patterns in Metallurgical and Nonmetallic Mineral Processing (Phase 6-Energy Data and Flowsheets, Low Priority Commodities) (Columbus: Battelle-Columbus Laboratories, 1976).

17. X. Bo, Y. Zhao, G. Meng, Y. Shang, and M. Fei, China Min. Mag. 18, 6 (2009).

18. J. Cheng and L. Che, J. Chin. Rare Earths 31, 65 (2010).

19. J.G. Parker, C.T. Baroch, and J.W. Adams, The Rare-Earth Elements, Yttrium, and Thorium: A Materials Survey (Denver: U.S. Bureau of Mines, 1971), p. 92.

20. D. Barthelmy, The Mineralogy Database (1997), http:// webmineral.com. Accessed Apr 2012.

21. D. Schueler, M. Buchert, R. Liu, S. Dittrich, and C. Merz, Study on Rare Earths and Their Recycling-Final Report for The Greens/EFA Group in the European Parliament (Darmstadt: Oeko-Institut e. V., 2011).

22. A. Leveque, J.L. Sabot, and P. Maestro, Kirk-Othmer Encyclopedia of Chemical Technology (New York: Wiley, 2001).

23. US National Institute of Standards and Technology, NIST Chemistry WebBook (Gaithersburg, MD: National Institute Standards and Technology, 2013).

24. European Commission, Reference Document on Best Available Techniques in the Cement, Lime and Magnesium Oxide Manufacturing Industries (Brussels, Belgium: European Commission, 2010), p. 277.

25. M. Kul, Y. Topkaya, and I. Karakaya, Hydrometallurgy 93, 129 (2008).

26. P.R. Kruesi and G. Duker, J. Met. 17, 847 (1965).
27. P. Krumholz, Brazilian Practice for Monazite Treatment (Bombay: Rare Earth, 1957).

28. R. Vijayalakshmi, S.L. Mishra, H. Singh, and C.K. Gupta, Hydrometallurgy 61, 75 (2001).

29. N.E. Topp, The Chemistry of Rare Earth Elements (Amsterdam: Elsevier, 1965).

30. F.M. Lever and J.B. Payne, Advances in Extractive Metallurgy (London: The Institution of Mining and Metallurgy, 1968), pp. 789-804.

31. D.F. Peppard, J.P. Faris, P.R. Gray, and G.W. Mason, J. Phys. Chem. 57, 294 (1953).

32. D.F. Peppard, G.W. Mason, W.J. Driscoll, and R.J. Sironen, J. Inorg. Nucl. Chem. 7, 276 (1958).

33. D. Weaver, F.A. Kappelmann, and A.C. Topp, J. Am. Chem. Soc. 75, 3943 (1953).

34. R.G. Bautista, Handbook on the Physics and Chemistry of Rare Earths, ed. K.A. Gschneidner and L. Eyring (Amsterdam: Elsevier Science, 1995), pp. 1-27.

35. R.H. Perry and C.H. Chilton, Chemical Engineer's Handbook, 5th ed. (New York: McGraw-Hill, 2009).

36. A.D. Ryon, F.L. Daley, and R.S. Lowrie, Design and Scale Up of Mixer-Settlers for the Dapex Solvent Extraction Process (Oak Ridge: Oak Ridge National Laboratory, 1960).

37. Y. Çengel and M. Boles, Thermodynamics: An Engineering Approach, 4th ed. (New York: McGraw-Hill, 2002).

38. F.T. Parada and E. Asselin, JOM 61, 54 (2009).

39. E.S. Shedd, J.D. Marchant, and M.M. Wong, Electrowinning Misch Metal from a Treated Bastnäsite Concentrate, Bureau of Mines Report of Investigations 7398 (Washington, D.C: U.S. Department of Interior, 1970). 